Article

\title{
New Method of Avoiding Underestimation of Caries Incidence and Its Association with Possible Risk Factors in Japanese University Students: A Prospective Cohort Study
}

\author{
Daisuke Ekuni $^{1, *(\mathbb{D})}$, Naoki Toyama ${ }^{1}$ D, Yoshiaki Iwasaki ${ }^{2}$ and Manabu Morita ${ }^{1}$ \\ 1 Department of Preventive Dentistry, Graduate School of Medicine, Dentistry and Pharmaceutical Sciences, \\ Okayama University, 2-5-1, Shikata-cho, Kita-ku, Okayama 700-8558, Japan; \\ pu171qxi@s.okayama-u.ac.jp (N.T.); mmorita@md.okayama-u.ac.jp (M.M.) \\ 2 Health Service Center, Okayama University, 2-1-1, Tsushima-naka, Kita-ku, Okayama 700-8530, Japan; \\ yiwasaki@okayama-u.ac.jp \\ * Correspondence: dekuni7@md.okayama-u.ac.jp
}

check for

updates

Citation: Ekuni, D.; Toyama, N.;

Iwasaki, Y.; Morita, M. New Method of Avoiding Underestimation of Caries Incidence and Its Association with Possible Risk Factors in Japanese University Students: A Prospective Cohort Study. Int. J. Environ. Res. Public Health 2022, 19, 2490. https:// doi.org/10.3390/ijerph19042490

Academic Editors: Kelvin Afrashtehfar and Paul B. Tchounwou

Received: 13 January 2022

Accepted: 18 February 2022

Published: 21 February 2022

Publisher's Note: MDPI stays neutral with regard to jurisdictional claims in published maps and institutional affiliations.

Copyright: (C) 2022 by the authors. Licensee MDPI, Basel, Switzerland. This article is an open access article distributed under the terms and conditions of the Creative Commons Attribution (CC BY) license (https:// creativecommons.org/licenses/by/ $4.0 /)$.

\begin{abstract}
The objective of this three-year prospective cohort study was to investigate the association between a new definition of an increase in dental caries and risk factors in Japanese young adults. Data of Okayama University students who volunteered to undergo oral examinations and answer questionnaires in 2015 and 2018 were analyzed. The status of filled teeth and the status of occlusal/proximal surfaces of filled or decayed teeth were recorded. An increase in dental caries was defined as a change in the status of filled teeth and/or an increase in dental caries of occlusal and proximal surfaces. A total of 393 participants (18.2 \pm 0.8 years) were analyzed. First and second molars showed a high prevalence of dental caries. Of the participants, 144 (36.6\%) showed an increase in dental caries. In all the participants and in the females, the decayed, missing, and filled teeth (DMFT) score and history of orthodontic treatment at baseline were significantly associated with an increase in dental caries $(p<0.05)$ in logistic regression analyses. In the males, the DMFT score and the daily frequency of snacking $(\geq 2)$ at baseline were significantly associated with an increase in dental caries $(p=0.04)$. The DMFT score and history of orthodontic treatment at baseline can be risk factors for an increase in dental caries using the new definition in young adults.
\end{abstract}

Keywords: dental caries; risk factors; disease progression; cohort studies

\section{Introduction}

Dental caries is one of the most prevalent oral diseases worldwide [1]. It has negative impacts on oral health and quality of life [2] and is one of the main reasons for the extraction of permanent teeth in Japan [3]. Dental caries is a multifactorial disease involving interactions between the diet, the host, and the microorganisms over time [4], as well as other risk factors [5-9].

Although global evidence shows that the prevalence of dental caries has been decreasing over the past four decades, this trend is mainly observed in high-income countries, and its decline is seen in 12-year-old children [10,11]. According to the national data in Japan, the dental caries prevalence among school children has decreased over the last 30 years [12]. The decayed, missing, and filled teeth (DMFT) score reached 0.70 for 12 -yearold children in 2020 [12]. However, dental caries prevalence is still high in young adults and increases from $31.76 \%$ at 12 years of age to $47.95 \%$ at 17 years of age [12]. Thus, dental caries remains a major problem and should be a focus in the promotion of oral health in young adults.

The index used most commonly for dental caries is the DMFT score [13]. However, the cohort studies using the DMFT system in epidemiological surveys have underestimated the history of dental caries because refilled dental materials and the increased number of 
decayed surfaces due to recurrent dental caries are not recorded. There are some cohort studies of young adults using the decayed, missing, and filled surfaces (DMFS) score that investigates the surfaces of each tooth [14-18]. However, this also cannot account for refilled dental materials. In fact, unlike in clinical studies, it is difficult to investigate refilled dental materials in epidemiological surveys without dental charts and X-ray scans. Thus, new definitions are required to avoid underestimation of dental caries incidence.

In order to avoid underestimation of dental caries incidence, we focused on the change in dental restoration, for example, from resin filling to metal inlay, and the increase in the number of dental surfaces with a history of caries in each tooth. There have been few epidemiological cohort studies that monitored such changes in dental caries history. In young adults, dental caries is mostly prevalent in occlusal surfaces, followed by proximal surfaces [19]. Therefore, the aim of this prospective cohort study was to investigate the association of caries incidence determined using this new approach and risk factors in Japanese young adults. We hypothesized that using this new approach to monitor changes in dental caries would avoid underestimation of dental caries incidence and allow the identification of previously unknown risk factors.

\section{Materials and Methods}

\subsection{Study Design and Setting}

This was a 3-year prospective cohort study. The baseline recruitment was performed in April 2015. Re-examination at follow-up was performed 3 years after the baseline examination (April 2018). The study location was the Okayama University Health Service Center at Okayama University of Japan.

\subsection{Participants}

The study participants were recruited from the first-year students of Okayama University in 2015. These students were undergraduate students from all faculties who volunteered to undergo an oral examination and answer questionnaires at the Okayama University Health Service Center in April 2015. Some of them then volunteered to undergo an oral examination and answer questionnaires during the follow-up survey in April 2018. Included were the students who agreed to participate in the study and for whom complete data of both the oral examination and the questionnaires were available. Excluded were the students who did not undergo the oral examination or for whom only incomplete data were available.

\subsection{Ethics Procedures and Informed Consent}

The study protocol was approved by the Ethics Committee of the Okayama University Graduate School of Medicine, Dentistry, and Pharmaceutical Sciences and the Okayama University Hospital (No. 1060). All the participants provided verbal informed consent for participation in this study. All the methods were performed in accordance with the relevant guidelines and regulations. The present study was performed in accordance with the STROBE Statement.

\subsection{Oral Examination}

Six trained dentists (T.A., S.M., K.K., M.Y.-T., A.T.-T. and D.E.) performed oral examinations. The number of teeth present including third molars was recorded at baseline and follow-up. The World Health Organization (WHO) diagnostic criteria for history of dental caries [13] were used to evaluate the DMFT score. Furthermore, the status of filled teeth (amalgam filling/resin filling/metal inlay/full-coverage crown) and of occlusal (foramen cecum/incisal in case of anterior teeth) and proximal surfaces of filled or decayed teeth was recorded at baseline and follow-up.

A modified version of the Index of Orthodontic Treatment Need [20] was used to evaluate malocclusion at baseline. The oral hygiene status was evaluated by visually inspecting selected teeth based on the Debris Index-Simplified (DI-S) [21]. The dentists 
repeatedly practiced the dental caries and malocclusion evaluations in two volunteers for two weeks. For the oral examination, intra- and inter-agreements were good (Kappa statistic > 0.8).

\subsection{Questionnaire}

Self-reported questionnaires on risk factors for dental caries were used at baseline based on the previous reports [22-24], including age, sex (male/female), use of fluoride toothpaste (yes/no), knowledge of the effectiveness of fluoride (yes/no), history of topical application of fluoride in elementary, junior high, and high schools (yes/discontinued/never), daily frequency of tooth brushing $(\geq 2 /<2)$, daily frequency of snacking $(\geq 2 /<2)$, smoking status (current/past/never), use of a dental floss (yes/no), history of orthodontic treatment (yes/no), regular dental checkups (yes/no), and dry mouth (yes/no). Since the WHO recommends twice-daily tooth brushing with a fluoride toothpaste to prevent dental caries, the two questionnaires were combined, and "daily frequency of tooth brushing with a fluoride toothpaste" $(\geq 2 /<2)$ was used.

\subsection{Main Outcome}

The main outcome of this study was an increase in dental caries. An increase in dental caries was defined as an increase in the DMFT score and/or changes in the status of filled teeth, and/or an increase in dental caries of occlusal and proximal surfaces during the 3-year study period. The participants were then classified into the increase and no-increase groups.

\subsection{Bias}

The dentists encouraged the patients to undergo re-examinations to avoid dropouts (attrition bias). Calibrated methods were used to minimize information bias. All cases without incomplete data were used, and students with and without follow-up were compared to check for selection bias.

\subsection{Sample Size Estimation}

Since there were no previous reports that investigated the association between an increase in dental caries using our definitions and risk factors, sample size estimation was not performed.

\subsection{Statistical Analysis}

The Mann-Whitney $U$ test, chi-squared test, or Fisher's exact test was used to assess significant differences in variables between the two groups. The Wilcoxon signed-rank test or McNemar's test was used to assess significant differences in variables between the baseline and the follow-up. The associations between an increase in dental caries and all the independent variables that are risk factors for dental caries were analyzed by means of logistic regression. Subgroup analyses by sex were also performed. All the missing data were excluded in this study. All the analyses were performed using SPSS $25.0 \mathrm{~J}$ for Windows (IBM Japan, Tokyo, Japan). Values of $p<0.05$ were considered significant.

\section{Results}

Figure 1 shows the study flowchart. Of the 2053 participants who completed the oral examination and the questionnaire, 393 participants were analyzed after 3 years (follow-up rate: $19.1 \%$ ). There were no significant differences in the related factors at baseline between the participants with follow-up and the students without follow-up. 


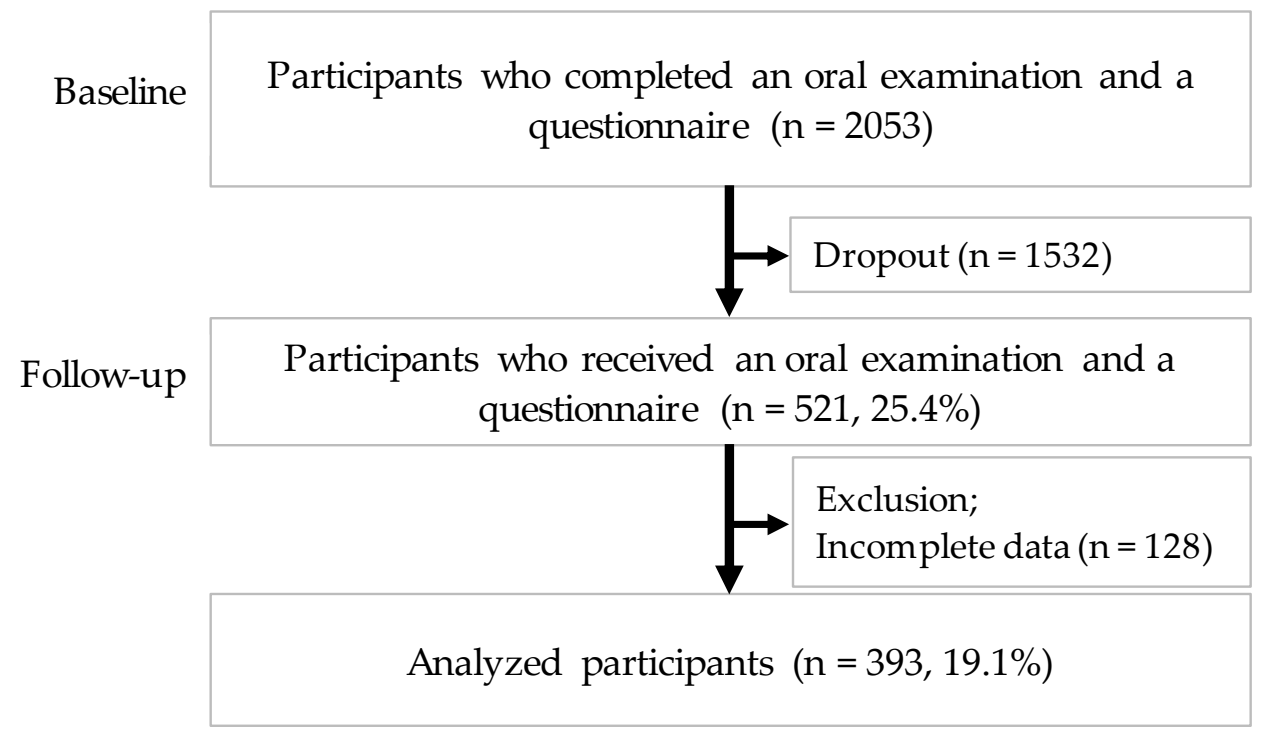

Figure 1. Flowchart of the study.

Table 1 shows the characteristics of the participants at baseline. Overall, the mean age at baseline ( \pm the standard deviation (SD)) of the analyzed participants was $18.2 \pm 0.8$ (median, 18.0; range, 18-29) years. The mean DMFT score at baseline ( \pm the standard deviation) was $1.6 \pm 2.8$ (median, 0.0 ; range, $0.0-22.0$ ). The number (\%) of dental caries-free participants $(\mathrm{DMFT}=0)$ at baseline was $220(56.0 \%)$. There were no participants with dry mouth.

Table 1. Characteristics of the participants at baseline $(n=393)$.

\begin{tabular}{|c|c|c|}
\hline Variable & & $n(\%) /$ Mean \pm SD \\
\hline Sex & Male/female & $210 / 183(53.4 / 46.6)$ \\
\hline Age $(y)$ & & $18.2 \pm 0.8$ \\
\hline Number of teeth present & & $28.4 \pm 1.5$ \\
\hline DMFT score & & $1.6 \pm 2.8$ \\
\hline Caries-free $(\mathrm{DMFT}=0)$ & Yes & $220(56.0)$ \\
\hline DI-S & & $0.4 \pm 0.4$ \\
\hline Malocclusion & Yes & $139(35.4)$ \\
\hline Use of a fluoride toothpaste & Yes & $172(43.8)$ \\
\hline \multirow{4}{*}{$\begin{array}{l}\text { Knowledge of the effectiveness of fluoride } \\
\text { History of topical application of fluoride in elementary, junior high, } \\
\text { and high schools }\end{array}$} & Yes & $110(28.0)$ \\
\hline & Yes & $83(21.1)$ \\
\hline & Discontinued & $174(44.3)$ \\
\hline & Never & $136(34.6)$ \\
\hline Daily frequency of tooth brushing & $<2$ & $43(10.9)$ \\
\hline Daily frequency of tooth brushing with a fluoride toothpaste & $<2$ & $191(48.6)$ \\
\hline Daily frequency of snacking & $\geq 2$ & $89(22.6)$ \\
\hline \multirow[t]{3}{*}{ Smoking } & Never & $391(99.5)$ \\
\hline & Past & $1(0.3)$ \\
\hline & Current & $1(0.3)$ \\
\hline Use of a dental floss & No & $339(86.3)$ \\
\hline History of orthodontic treatment & Yes & $75(19.1)$ \\
\hline Regular dental checkups & No & $289(73.5)$ \\
\hline Awareness of dry mouth & Yes & $0(0.0)$ \\
\hline
\end{tabular}

SD, standard deviation; DMFT, decayed, missing, and filled teeth; DI-S, Debris Score.

The mean DMFT score at follow-up $( \pm \mathrm{SD})$ was $2.5 \pm 3.7$ (median, 1.0; range, 0.0-22.0). It increased significantly (Wilcoxon signed-rank test, $p<0.001$ ), and the number of dental caries-free participants decreased significantly during the 3-year period (from 220 to 176; McNemar's test, $p<0.001)$. 
Table 2 shows the tooth type and changes in dental caries. The highest prevalence of decayed teeth was the upper second molar at baseline and the upper third molar at follow-up. Missing teeth were only observed in the third molar at follow-up. The highest prevalence of filled teeth was the lower first molar at baseline and follow-up. The highest increase in dental caries was observed in the upper second molar during the 3-year period (72 teeth). The major status of filled teeth was resin. The major surface of filled teeth was the occlusal surface. The highest prevalence of dental caries in the occlusal surface was the lower first molar at baseline and follow-up.

Table 2. Tooth type and changes in the history of dental caries.

\begin{tabular}{|c|c|c|c|c|c|}
\hline $\begin{array}{l}\text { Tooth } \\
\text { Type }\end{array}$ & $\begin{array}{l}\text { Number of } \\
\text { Teeth Present }\end{array}$ & $\begin{array}{l}\text { Number of } \\
\text { Decayed } \\
\text { Teeth }\end{array}$ & $\begin{array}{l}\text { Number of } \\
\text { Missing } \\
\text { Teeth }\end{array}$ & $\begin{array}{l}\text { Number of Filled Teeth and Status } \\
\text { (Amalgam Filling/Resin Filling/Metal } \\
\text { Inlay/Full-Coverage Crown) }\end{array}$ & $\begin{array}{c}\text { Surfaces of Filled Teeth: } \\
\text { Occlusal/Proximal/ } \\
\text { Occlusal + Proximal }\end{array}$ \\
\hline \multicolumn{6}{|c|}{ Upper at baseline } \\
\hline 8 & 112 & 1 & 0 & $4(0 / 4 / 0 / 0)$ & $4 / 0 / 0$ \\
\hline 7 & 780 & 14 & 0 & $62(0 / 48 / 13 / 1)$ & $45 / 16 / 1$ \\
\hline 6 & 786 & 7 & 0 & $104(1 / 72 / 28 / 3)$ & $79 / 22 / 3$ \\
\hline 5 & 776 & 2 & 0 & $24(0 / 7 / 17 / 0)$ & $4 / 20 / 0$ \\
\hline 4 & 758 & 2 & 0 & $15(0 / 4 / 11 / 0)$ & $4 / 11 / 0$ \\
\hline 3 & 780 & 0 & 0 & $4(0 / 4 / 0 / 0)$ & $1 / 3 / 0$ \\
\hline 2 & 777 & 0 & 0 & $20(0 / 20 / 0 / 0)$ & $5 / 15 / 0$ \\
\hline 1 & 786 & 5 & 0 & $30(0 / 28 / 0 / 2)$ & $6 / 22 / 2$ \\
\hline \multicolumn{6}{|c|}{ Lower at baseline } \\
\hline 8 & 140 & 1 & 0 & $0(0 / 0 / 0 / 0)$ & $0 / 0 / 0$ \\
\hline 7 & 785 & 3 & 0 & $126(0 / 114 / 11 / 1)$ & $111 / 14 / 1$ \\
\hline 6 & 786 & 8 & 0 & $181(2 / 151 / 26 / 2)$ & $162 / 17 / 2$ \\
\hline 5 & 781 & 2 & 0 & $14(0 / 6 / 7 / 1)$ & $5 / 8 / 1$ \\
\hline 4 & 775 & 1 & 0 & $4(0 / 3 / 1 / 0)$ & $3 / 1 / 0$ \\
\hline 3 & 775 & 0 & 0 & $1(0 / 1 / 0 / 0)$ & $0 / 1 / 0$ \\
\hline 2 & 768 & 0 & 0 & $0(0 / 0 / 0 / 0)$ & $0 / 0 / 0$ \\
\hline 1 & 786 & 0 & 0 & $0(0 / 0 / 0 / 0)$ & $0 / 0 / 0$ \\
\hline \multicolumn{6}{|c|}{ Upper at follow-up } \\
\hline 8 & 263 & 8 & 5 & $3(0 / 3 / 0 / 0)$ & $3 / 0 / 0$ \\
\hline 7 & 784 & 9 & 0 & $134(0 / 109 / 21 / 4)$ & $100 / 30 / 4$ \\
\hline 6 & 786 & 0 & 0 & $164(1 / 122 / 31 / 10)$ & $118 / 36 / 10$ \\
\hline 5 & 776 & 2 & 0 & $43(0 / 16 / 23 / 4)$ & $8 / 31 / 4$ \\
\hline 4 & 758 & 0 & 0 & $33(0 / 19 / 14 / 0)$ & $10 / 23 / 0$ \\
\hline 3 & 780 & 0 & 0 & $7(0 / 7 / 0 / 0)$ & $2 / 5 / 0$ \\
\hline 2 & 777 & 2 & 0 & $31(0 / 31 / 0 / 0)$ & $7 / 24 / 0$ \\
\hline 1 & 786 & 6 & 0 & $61(0 / 55 / 1 / 5)$ & $8 / 48 / 5$ \\
\hline \multicolumn{6}{|c|}{ Lower at follow-up } \\
\hline 8 & 263 & 2 & 4 & $5(0 / 5 / 0 / 0)$ & $5 / 0 / 0$ \\
\hline 7 & 786 & 4 & 0 & $195(0 / 174 / 14 / 7)$ & $165 / 23 / 7$ \\
\hline 6 & 786 & 3 & 0 & $242(0 / 205 / 31 / 6)$ & $206 / 30 / 6$ \\
\hline 5 & 769 & 1 & 0 & $28(0 / 17 / 9 / 2)$ & $13 / 13 / 2$ \\
\hline 4 & 768 & 1 & 0 & $9(0 / 6 / 3 / 0)$ & $6 / 3 / 0$ \\
\hline 3 & 775 & 0 & 0 & $2(0 / 2 / 0 / 0)$ & $1 / 1 / 0$ \\
\hline 2 & 766 & 0 & 0 & $0(0 / 0 / 0 / 0)$ & $0 / 0 / 0$ \\
\hline 1 & 786 & 0 & 0 & $1(0 / 0 / 0 / 1)$ & $0 / 0 / 1$ \\
\hline
\end{tabular}

Table 3 shows the differences in baseline factors between the increase and no-increase groups. According to the new definition of an increase in caries, $144(36.6 \%)$ of the 393 students showed an increase in dental caries. Of them, nine $(2.3 \%)$ students were underestimated compared to the cases with an increase in the DMFT score. The DMFT score at baseline was significantly higher in the increase group than in the no-increase 
group among all the participants, males, and females (all, $p<0.001$ ). The prevalence of the history of orthodontic treatment was significantly higher at baseline in the increase group than in the no-increase group among all the participants $(p=0.004)$ and the females $(p=0.002)$. In the males, the prevalence of a high frequency of snacking ( $\geq 2$ /day) was significantly higher in the increase group than in the no-increase group $(p=0.021)$.

Table 3. Differences in baseline factors between the increase and no-increase groups.

\begin{tabular}{|c|c|c|c|c|}
\hline \multicolumn{5}{|l|}{ Total } \\
\hline Variable & & $\begin{array}{l}\text { Increase } \\
(n=144)\end{array}$ & $\begin{array}{l}\text { No Increase } \\
\quad(n=249)\end{array}$ & $p$-Value ${ }^{\dagger}$ \\
\hline Sex & Male & $75(52.1) *$ & $135(54.2)$ & 0.683 \\
\hline Age (year) & & $18.3 \pm 1.0$ & $18.2 \pm 0.6$ & 0.721 \\
\hline Number of teeth present & & $28.3 \pm 1.4$ & $28.5 \pm 1.5$ & 0.292 \\
\hline DMFT score & & $2.9 \pm 3.6$ & $0.9 \pm 1.9$ & $<0.001$ \\
\hline DI-S & & $0.4 \pm 0.4$ & $0.4 \pm 0.4$ & 0.822 \\
\hline Malocclusion & Yes & $50(34.7)$ & $89(35.7)$ & 0.913 \\
\hline \multirow{4}{*}{$\begin{array}{l}\text { Knowledge of the effectiveness of fluoride } \\
\text { History of topical application of fluoride in elementary, } \\
\text { junior high, and high schools }\end{array}$} & No & $38(26.4)$ & $72(28.9)$ & 0.338 \\
\hline & Yes & $36(25.0)$ & $47(18.9)$ & 0.332 \\
\hline & Discontinued & $59(41.0)$ & $115(46.2)$ & \\
\hline & Never & $49(34.0)$ & $87(34.9)$ & \\
\hline Daily frequency of tooth brushing with a fluoride toothpaste & $<2$ & $68(47.2)$ & $123(49.4)$ & 0.378 \\
\hline Daily frequency of snacking & $\geq 2$ & $37(25.7)$ & $52(20.9)$ & 0.272 \\
\hline \multirow{3}{*}{ Smoking } & Never & $143(99.3)$ & $248(99.6)$ & 0.315 \\
\hline & Past & $0(0.0)$ & $1(0.3)$ & \\
\hline & Current & $1(0.3)$ & $0(0.0)$ & \\
\hline Use of a dental floss & No & $124(86.1)$ & $215(86.3)$ & 0.948 \\
\hline History of orthodontic treatment & Yes & $38(26.4)$ & $37(14.9)$ & 0.004 \\
\hline Regular dental checkups & No & $105(72.9)$ & $184(73.9)$ & 0.832 \\
\hline Males & & $\begin{array}{c}\text { Increase } \\
(n=75)\end{array}$ & $\begin{array}{l}\text { No increase } \\
\quad(n=135)\end{array}$ & $p$-Value \\
\hline Age (year) & & $18.4 \pm 1.4$ & $18.3 \pm 0.7$ & 0.793 \\
\hline Number of teeth present & & $28.4 \pm 1.6$ & $28.6 \pm 1.5$ & 0.660 \\
\hline DMFT score & & $2.6 \pm 3.3$ & $0.9 \pm 2.2$ & $<0.001$ \\
\hline DI-S & & $0.5 \pm 0.4$ & $0.4 \pm 0.4$ & 0.568 \\
\hline Malocclusion & Yes & $26(34.7)$ & $44(32.6)$ & 0.760 \\
\hline \multirow{4}{*}{$\begin{array}{l}\text { Knowledge of the effectiveness of fluoride } \\
\text { History of topical application of fluoride in elementary, } \\
\text { junior high, and high schools }\end{array}$} & No & $27(36.0)$ & $45(33.3)$ & 0.696 \\
\hline & Yes & $18(24.0)$ & $24(17.8)$ & 0.540 \\
\hline & Discontinued & $26(34.7)$ & $53(39.3)$ & \\
\hline & Never & $31(41.3)$ & $58(43.0)$ & \\
\hline Daily frequency of tooth brushing with a fluoride toothpaste & $<2$ & $35(46.7)$ & $62(54.9)$ & 0.918 \\
\hline Daily frequency of snacking & $\geq 2$ & $22(29.3)$ & $22(16.3)$ & 0.021 \\
\hline \multirow[t]{3}{*}{ Smoking } & Never & $74(98.7)$ & $134(99.3)$ & 0.308 \\
\hline & Past & $1(1.3)$ & $0(0.0)$ & \\
\hline & Current & $0(0.0)$ & $1(0.7)$ & \\
\hline Use of a dental floss & No & $70(93.3)$ & $117(86.7)$ & 0.103 \\
\hline History of orthodontic treatment & Yes & $13(17.3)$ & $19(14.1)$ & 0.529 \\
\hline Regular dental checkups & No & $53(70.7)$ & $101(74.8)$ & 0.515 \\
\hline Females & & $\begin{array}{l}\text { Increase } \\
(n=69)\end{array}$ & $\begin{array}{l}\text { No increase } \\
(n=114)\end{array}$ & $p$-Value \\
\hline Age (year) & & $18.1 \pm 0.4$ & $18.2 \pm 0.4$ & 0.398 \\
\hline Number of teeth present & & $28.2 \pm 1.3$ & $28.4 \pm 1.5$ & 0.307 \\
\hline DMFT score & & $2.8 \pm 3.9$ & $0.8 \pm 1.6$ & $<0.001$ \\
\hline DI-S & & $0.3 \pm 0.3$ & $0.3 \pm 0.3$ & 0.878 \\
\hline Malocclusion & Yes & $24(34.8)$ & $45(39.5)$ & 0.318 \\
\hline Knowledge of the effectiveness of fluoride & No & $11(15.9)$ & $27(23.7)$ & 0.143 \\
\hline
\end{tabular}


Table 3. Cont.

\begin{tabular}{|c|c|c|c|c|}
\hline Total & & & & \\
\hline Variable & & $\begin{array}{l}\text { Increase } \\
(n=144)\end{array}$ & $\begin{array}{l}\text { No Increase } \\
\quad(n=249)\end{array}$ & $p$-Value ${ }^{\dagger}$ \\
\hline \multirow{3}{*}{$\begin{array}{l}\text { History of topical application of fluoride in elementary, } \\
\text { junior high, and high schools }\end{array}$} & Yes & $18(26.1)$ & $23(20.2)$ & 0.596 \\
\hline & Discontinued & $33(47.8)$ & $62(54.4)$ & \\
\hline & Never & $18(26.1)$ & $29(25.4)$ & \\
\hline Daily frequency of tooth brushing with a fluoride toothpaste & $<2$ & $33(47.8)$ & $61(53.5)$ & 0.277 \\
\hline Daily frequency of snacking & $\geq 2$ & $15(21.7)$ & $30(26.3)$ & 0.304 \\
\hline \multirow[t]{3}{*}{ Smoking } & Never & $69(100.0)$ & $114(100.0)$ & - \\
\hline & Past & $0(0.0)$ & $0(0.0)$ & \\
\hline & Current & $0(0.0)$ & $0(0.0)$ & \\
\hline Use of a dental floss & No & $54(78.3)$ & $98(86.0)$ & 0.178 \\
\hline History of orthodontic treatment & Yes & $25(36.2)$ & $18(15.8)$ & 0.002 \\
\hline Regular dental checkups & No & $52(75.4)$ & $83(72.8)$ & 0.420 \\
\hline
\end{tabular}

* Note: $n(\%) /$ mean \pm standard deviation; ${ }^{\dagger}$ Fisher's exact/chi-squared/Mann-Whitney $U$ tests; DMFT, decayed missing and filled teeth; DI-S, Debris Score-Simplified.

Table 4 shows the results of logistic regression analyses. In all the participants and the females, the DMFT score and the history of orthodontic treatment at baseline were significantly associated with an increase in dental caries (both $p<0.05$ ). In the males, the DMFT score and the daily frequency of snacking $(\geq 2)$ were significantly associated with an increase in dental caries (both $p<0.05$ ).

Table 4. Risk factors at baseline for an increase in dental caries in logistic regression analyses.

\begin{tabular}{|c|c|c|c|}
\hline Total $(n=393)$ & & & \\
\hline Independent Variable & & $\begin{array}{l}\text { Adjusted Odds Ratio, }{ }^{*} 95 \% \\
\text { Confidence Interval }\end{array}$ & $p$-Value \\
\hline \multirow[t]{2}{*}{ Sex } & Male (reference) & 1 & \\
\hline & Female & $1.077,0.676-1.716$ & 0.755 \\
\hline Age $(y)$ & & $0.993,0.743-1.328$ & 0.963 \\
\hline Number of teeth present & & $0.944,0.810-1.100$ & 0.459 \\
\hline DMFT score & & $1.345,1.214-1.490$ & $<0.001$ \\
\hline DI-S & & $1.055,0.565-1.970$ & 0.866 \\
\hline \multirow[t]{2}{*}{ Malocclusion } & No (reference) & 1 & \\
\hline & Yes & $1.082,0.673-1.738$ & 0.745 \\
\hline \multirow[t]{2}{*}{ Knowledge of the effectiveness of fluoride } & Yes (reference) & 1 & \\
\hline & No & $0.855,0.499-1.465$ & 0.569 \\
\hline \multirow[t]{3}{*}{$\begin{array}{l}\text { History of topical application of fluoride in } \\
\text { elementary, junior high, and high schools }\end{array}$} & Yes (reference) & 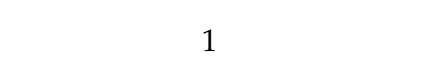 & \\
\hline & Discontinued & $0.918,0.496-1.701$ & 0.786 \\
\hline & Never & $0.985,0.494-1.961$ & 0.965 \\
\hline \multirow[t]{2}{*}{$\begin{array}{l}\text { Daily frequency of tooth brushing with a } \\
\text { fluoride toothpaste }\end{array}$} & $\geq 2$ (reference) & 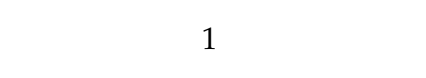 & \\
\hline & $<2$ & $0.875,0.555-1.378$ & 0.564 \\
\hline \multirow[t]{2}{*}{ Daily frequency of snacking } & $<2$ (reference) & 1 & \\
\hline & $\geq 2$ & $1.196,0.707-2.031$ & 0.507 \\
\hline \multirow[t]{2}{*}{ Use of a dental floss } & Yes (reference) & 1 & \\
\hline & No & $1.135,0.574-2.255$ & 0.718 \\
\hline \multirow[t]{2}{*}{ History of orthodontic treatment } & No & 1 & \\
\hline & Yes (reference) & $1.976,1.100-3.549$ & 0.023 \\
\hline \multirow[t]{2}{*}{ Regular dental checkups } & Yes (reference) & 1 & \\
\hline & No & $1.127,0.647-1.978$ & 0.675 \\
\hline \multicolumn{4}{|l|}{ Males $(n=210)$} \\
\hline Age (y) & & $1.049,0.763-1.442$ & 0.770 \\
\hline
\end{tabular}


Table 4. Cont.

\begin{tabular}{|c|c|c|c|}
\hline \multicolumn{4}{|l|}{ Total $(n=393)$} \\
\hline Independent Variable & & $\begin{array}{l}\text { Adjusted Odds Ratio, } * 95 \% \\
\text { Confidence Interval }\end{array}$ & $p$-Value \\
\hline Number of teeth present & & $0.988,0.802-1.219$ & 0.913 \\
\hline DMFT score & & $1.312,1.155-1.490$ & $<0.001$ \\
\hline DI-S & & $1.127,0.508-2.501$ & 0.768 \\
\hline Malocclusion & No (reference) & 1 & \\
\hline \multirow{3}{*}{ Knowledge of the effectiveness of fluoride } & Yes & $1.039,0.534-2.021$ & 0.911 \\
\hline & Yes (reference) & 1 & \\
\hline & No & $1.062,0.537-2.100$ & 0.864 \\
\hline \multirow[t]{3}{*}{$\begin{array}{l}\text { History of topical application of fluoride in } \\
\text { elementary, junior high, and high schools }\end{array}$} & Yes (reference) & 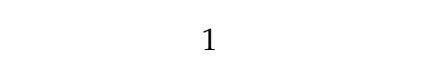 & \\
\hline & Discontinued & $0.997,0.408-2.433$ & 0.995 \\
\hline & Never & $0.817,0.329-2.033$ & 0.664 \\
\hline \multirow[t]{2}{*}{$\begin{array}{l}\text { Daily frequency of tooth brushing with a } \\
\text { fluoride toothpaste }\end{array}$} & $\geq 2$ (reference) & 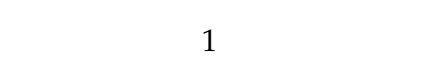 & \\
\hline & $<2$ & $1.003,0.534-1.887$ & 0.992 \\
\hline \multirow[t]{2}{*}{ Daily frequency of snacking } & $<2$ (reference) & 1 & \\
\hline & $\geq 2$ & $2.183,1.037-4.597$ & 0.040 \\
\hline \multirow[t]{2}{*}{ Use of a dental floss } & Yes (reference) & 1 & \\
\hline & No & $2.537,0.755-8.519$ & 0.132 \\
\hline \multirow[t]{2}{*}{ History of orthodontic treatment } & No & 1 & \\
\hline & Yes (reference) & $1.125,0.467-2.711$ & 0.793 \\
\hline \multirow[t]{2}{*}{ Regular dental checkups } & Yes (reference) & 1 & \\
\hline & No & $0.835,0.395-1.766$ & 0.637 \\
\hline \multicolumn{4}{|l|}{ Females $(n=183)$} \\
\hline Age $(y)$ & & $0.908,0.357-2.309$ & 0.839 \\
\hline Number of teeth present & & $0.892,0.699-1.137$ & 0.355 \\
\hline DMFT score & & $1.445,1.208-1.729$ & $<0.001$ \\
\hline DI-S & & $1.023,0.351-2.977$ & 0.967 \\
\hline Malocclusion & No (reference) & 1 & \\
\hline \multirow{3}{*}{ Knowledge of the effectiveness of fluoride } & Yes & $1.064,0.518-2.183$ & 0.867 \\
\hline & Yes (reference) & 1 & \\
\hline & No & $0.447,0.165-1.209$ & 0.113 \\
\hline \multirow[t]{3}{*}{$\begin{array}{l}\text { History of topical application of fluoride in } \\
\text { elementary, junior high, and high schools }\end{array}$} & Yes (reference) & s & \\
\hline & Discontinued & $0.924,0.363-2.349$ & 0.868 \\
\hline & Never & $1.716,0.539-5.461$ & 0.361 \\
\hline \multirow[t]{2}{*}{$\begin{array}{l}\text { Daily frequency of tooth brushing with a } \\
\text { fluoride toothpaste }\end{array}$} & $\geq 2$ (reference) & 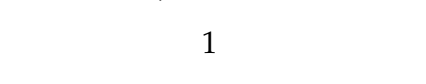 & \\
\hline & $<2$ & $0.769,0.381-1.550$ & 0.462 \\
\hline \multirow[t]{2}{*}{ Daily frequency of snacking } & $<2$ (reference) & 1 & \\
\hline & $\geq 2$ & $0.691,0.302-1.585$ & 0.383 \\
\hline Use of a dental floss & $\begin{array}{c}\text { Yes (reference) } \\
\text { No }\end{array}$ & $\begin{array}{c}1 \\
0.562,0.206-1.529\end{array}$ & 0.259 \\
\hline \multirow[t]{2}{*}{ History of orthodontic treatment } & No (reference) & 1 & \\
\hline & Yes & $3.329,1.392-7.966$ & 0.007 \\
\hline \multirow[t]{2}{*}{ Regular dental checkups } & Yes (reference) & 1 & \\
\hline & No & $1.886,0.737-4.822$ & 0.185 \\
\hline
\end{tabular}

* Adjusted for all the listed independent variables; odds ratio (95\% confidence interval); DMFT, decayed, missing, and filled teeth; DI-S, Debris Score-Simplified.

\section{Discussion}

This 3-year cohort study showed that the increase in dental caries using the new definition was significantly associated with the DMFT score and the history of orthodontic treatment at baseline among all the participants and the females. On the other hand, in the males, the increase in dental caries was significantly associated with the DMFT score 
and the daily frequency of snacking at baseline. To the best of our knowledge, this is the first study to show results that were confirmed using this new definition. The DMFT score, the history of orthodontic treatment, and the daily frequency of snacking at baseline may be risk factors for an increase in dental caries.

The history of dental caries (DMFT $>0$ ) at baseline was a risk factor for an increase in dental caries in university students aged 18-29 years. Previous cohort studies reported that a history of caries was a risk factor for dental caries incidence in people aged 2-30 years [17,25-28]. People with a history of dental caries (DMFT > 0) are usually classified as a risk group [26]. These findings support the present results. On the other hand, the findings in the present study suggest that it is important to prevent dental caries in students before they enter university. Dentists and healthcare providers should continue to provide and also expand public health methodology for dental caries prevention, including supervised regular use of fluoride mouth rinses [29] and water fluoridation [30].

In the males, a high frequency of snacking was a risk factor for an increase in dental caries. A cariogenic diet, including sugar, is an important risk factor for dental caries [31]. Sugar restriction (amount and frequency) is important for dental caries prevention [6]. Thus, especially for males, control of snacking may be an important strategy to implement for preventing an increase in dental caries during university life.

In the females, a history of orthodontic treatment was a risk factor for an increase in dental caries. The abundance of Streptococcus mutans increases during and after orthodontic treatment $[24,32]$. The number of females with a history of orthodontic treatment was significantly higher than that of males in the present study (43 vs. 32, $p<0.038$ ). Thus, only in females a history of orthodontic treatment may be related to an increase in dental caries.

Application of fluoride (history of topical application of fluoride in elementary, junior high, and high school and daily frequency of tooth brushing with a fluoride toothpaste) as well as knowledge of the effectiveness of fluoride was not associated with an increase in dental caries in university students. This may be due to the small number of students who use a fluoride toothpaste and have knowledge of the protective effects of fluoride despite the fact that the recent market share of fluoridated toothpastes in Japan was reported to be about $90 \%$ [33].

A review has suggested that when fluoride is appropriately used, the association between sugar consumption and dental caries is very low or absent [6]. An FDI World Dental Federation task group emphasized that dental caries should be considered a behavioral disease with a bacterial component and that it needs to be prevented [34]. Based on that recommendation, dentists should put an increased effort toward encouraging students to brush their teeth with a fluoridated toothpaste twice daily, as well as to reduce the frequency of sugar intake.

Unfortunately, the new definition of an increase in dental caries has limited utility. The hope was that the new definition would improve on a limitation of the DMFT/DMFS score and reduce the underestimation of the increase in caries in epidemiological studies without dental charts or X-ray scans. However, the difference between the new definition and the DMFT score was not large. That is, with the new definition, only nine additional participants $(2.3 \%)$ were detected compared to the original definition (increase in the DMFT score). Furthermore, the results of the logistic regression analysis using the case of an increase in the DMFT score were comparable to the present data (data not shown); i.e., the increase in the DMFT score was significantly associated with the DMFT score and the history of orthodontic treatment at baseline.

The new definition that evaluates the increase in dental caries may have some potential. Since middle-aged and elderly persons tend to receive treatment for dental caries or retreatment, changes in dental materials and increases in the number of surfaces with dental caries are more obvious than in young adults [35]. Even if a tooth with composite resin is replaced by a metal inlay due to recurrent caries, according to the original definition (DMFT score), there is no increase in dental caries. Thus, the new definition could be useful 
for avoiding underestimation of changes in dental caries among middle-aged and elderly persons in epidemiological surveys.

The highest increase in dental caries was observed in the upper second molar during the 3-year period (72 teeth) in this study. Dental caries of occlusal surfaces was the most prevalent. The highest prevalence of dental caries of occlusal surfaces was in the lower first molar at baseline and at follow-up. First and second molars overall have a high risk for dental caries, and the prevalence of dental caries in occlusal surfaces is higher than that in proximal surfaces [36-40]. The trend in the present study was supported by these previous reports.

In the present study, the mean DMFT scores $( \pm \mathrm{SD})$ at baseline and follow-up were $1.6 \pm 2.8$ and $2.5 \pm 3.7$, respectively, in the university students aged 18-29 years. Although the sample size and period in the present study differed from those in previous studies comprising young adults aged 18-24 years [22,41,42], the mean DMFT scores were within the same range. However, the mean DMFT scores in this study were lower than those reported in a Japanese national survey of dental diseases in 2016 (3.1 for those aged 15-24 years) [35].

The present study had some limitations. Firstly, the follow-up rate was low because undergoing an oral examination was voluntary. Although the students were encouraged to undergo the examination, many students did not participate. Thus, a selection bias may have been present, and it could lead to an overestimation or underestimation of the true relationship. However, there were no significant differences in the related factors at baseline between the participants with follow-up and the students without follow-up. Thus, the effects on the results might have been small. Secondly, possible confounders such as biological factors, socioeconomic factors [23], amount of the remaining tooth structure, or presence of the post and the core [43-45] were not considered in the present study. Future studies need to assess the effects of these factors. Third, all the participants were recruited from among students at Okayama University, which may limit the ability to extrapolate these findings to the general population of young people. Fourth, dental charts and X-ray scans were not used. Thus, the new definition could not distinguish the increase in dental caries if the refilled materials and the surfaces were the same. Fifth, more sensitive methods such as the ICDAS (International Caries Detection and Assessment System [46]) should have been used to detect dental caries. However, the ICDAS could not be used because cleaning the teeth and drying out the surfaces are required before the examination for that system. Regarding caries risk assessment, more standardized procedures, such as CARIOGRAM or the CAMBRA system, could not be used because clinical assessments are included [47]. Use of these systems should be considered in a future study. Finally, changes in the confounding variables over the three-year study period, which may have been a potential source of bias, could not be investigated.

\section{Conclusions}

This 3-year cohort study showed that the increase in dental caries using the new definition was significantly associated with the DMFT score and the history of orthodontic treatment at baseline among all the participants and the females. On the other hand, in the males, the increase in dental caries was significantly associated with the DMFT score and the daily frequency of snacking at baseline. It is important to prevent dental caries in students. For the early stages of life, dentists and healthcare providers should continue to both provide and expand the public health methodology for dental caries prevention.

Author Contributions: Conceptualization, D.E., Y.I. and M.M.; methodology, D.E. and M.M.; validation, N.T.; formal analysis, D.E.; investigation, N.T. and D.E.; data curation, D.E. and N.T.; writing-original draft preparation, D.E.; writing-review and editing, N.T. and M.M.; supervision, M.M.; project administration, M.M. All authors have read and agreed to the published version of the manuscript.

Funding: This research received no external funding. 
Institutional Review Board Statement: The study was conducted in accordance with the Declaration of Helsinki and approved by the Ethics Committee of the Okayama University Graduate School of Medicine, Dentistry, and Pharmaceutical Sciences and the Okayama University Hospital (No. 1060).

Informed Consent Statement: Informed consent was obtained from all the subjects involved in the study.

Data Availability Statement: All the relevant data are included in the manuscript.

Acknowledgments: The authors wish to thank Kota Kataoka, Ayano Taniguchi-Tabata (Department of Preventive Dentistry, Graduate School of Medicine, Dentistry, and Pharmaceutical Sciences, Okayama University, Japan), Tetsuji Azuma (Department of Community Oral Health, School of Dentistry, Asahi University, Japan), Mayu Yamane-Takeuchi and Hikari Saho, and Shinsuke Mizutani (Section of Geriatric Dentistry and Perioperative Medicine in Dentistry, Division of Maxillofacial Diagnostic and Surgical Sciences, Faculty of Dental Science, Kyushu University; OBT Research Center, Faculty of Dental Science, Kyushu University, Japan) for their support of this study.

Conflicts of Interest: The authors declare no conflict of interest.

\section{References}

1. Selwitz, R.H.; Ismail, A.I.; Pitts, N.B. Dental Caries. Lancet Lond. Engl. 2007, 369, 51-59. [CrossRef]

2. Do, L.G.; Spencer, A. Oral Health-Related Quality of Life of Children by Dental Caries and Fluorosis Experience. J. Public Health Dent. 2007, 67, 132-139. [CrossRef] [PubMed]

3. Suzuki, S.; Sugihara, N.; Kamijo, H.; Morita, M.; Kawato, T.; Tsuneishi, M.; Kobayashi, K.; Hasuike, Y.; Sato, T. Reasons for Tooth Extractions in Japan: The Second Nationwide Survey. Int. Dent. J. 2021, 15, 817-830. [CrossRef] [PubMed]

4. Keyes, P.H. Research in Dental Caries. J. Am. Dent. Assoc. 1939 1968, 76, 1357-1373. [CrossRef]

5. Teshome, A.; Muche, A.; Girma, B. Prevalence of Dental Caries and Associated Factors in East Africa, 2000-2020: Systematic Review and Meta-Analysis. Front. Public Health 2021, 9, 645091. [CrossRef]

6. van Loveren, C. Sugar Restriction for Caries Prevention: Amount and Frequency. Which Is More Important? Caries Res. 2019, 53, 168-175. [CrossRef]

7. Kumar, S.; Tadakamadla, J.; Kroon, J.; Johnson, N.W. Impact of Parent-Related Factors on Dental Caries in the Permanent Dentition of 6-12-Year-Old Children: A Systematic Review. J. Dent. 2016, 46, 1-11. [CrossRef]

8. Palacios, C.; Joshipura, K.; Willett, W. Nutrition and Health: Guidelines for Dental Practitioners. Oral Dis. 2009, 15, 369-381. [CrossRef]

9. Mejàre, I.; Axelsson, S.; Dahlén, G.; Espelid, I.; Norlund, A.; Tranæus, S.; Twetman, S. Caries Risk Assessment. A Systematic Review. Acta Odontol. Scand. 2014, 72, 81-91. [CrossRef]

10. Frencken, J.E.; Sharma, P.; Stenhouse, L.; Green, D.; Laverty, D.; Dietrich, T. Global Epidemiology of Dental Caries and Severe Periodontitis-A Comprehensive Review. J. Clin. Periodontol. 2017, 44 (Suppl. S18), S94-S105. [CrossRef]

11. Peres, M.A.; Macpherson, L.M.D.; Weyant, R.J.; Daly, B.; Venturelli, R.; Mathur, M.R.; Listl, S.; Celeste, R.K.; Guarnizo-Herreño, C.C.; Kearns, C.; et al. Oral Diseases: A Global Public Health Challenge. Lancet Lond. Engl. 2019, 394, 249-260. [CrossRef]

12. Ministry of Education, Culture, Sports, Science and Technology. Japanese National Survey for School Health; Ministry of Education, Culture, Sports, Science and Technology: Tokyo, Japan, 2020.

13. World Health Organization Oral Health Surveys: Basic Methods-5th Edition. Available online: https://www.who.int/ publications-detail-redirect/9789241548649 (accessed on 3 August 2021).

14. Foster Page, L.A.; Thomson, W.M. Caries Prevalence, Severity, and 3-Year Increment, and Their Impact upon New Zealand Adolescents' Oral-Health-Related Quality of Life. J. Public Health Dent. 2012, 72, 287-294. [CrossRef] [PubMed]

15. Källestål, C. The Effect of Five Years' Implementation of Caries-Preventive Methods in Swedish High-Risk Adolescents. Caries Res. 2005, 39, 20-26. [CrossRef] [PubMed]

16. Kruger, E.; Thomson, W.M.; Poulton, R.; Davies, S.; Brown, R.H.; Silva, P.A. Dental Caries and Changes in Dental Anxiety in Late Adolescence. Community Dent. Oral Epidemiol. 1998, 26, 355-359. [CrossRef] [PubMed]

17. David, J.; Raadal, M.; Wang, N.J.; Strand, G.V. Caries Increment and Prediction from 12 to 18 Years of Age: A Follow-up Study. Eur. Arch. Paediatr. Dent. 2006, 7, 31-37. [CrossRef]

18. Schmoeckel, J.; Santamaría, R.M.; Splieth, C.H. Long-Term Caries Development in Schoolchildren and the Role of Educational Status. Quintessence Int. 2015, 46, 409-415. [CrossRef]

19. Rosier, B.T.; van Loveren, C.; Zaura, E.; Loos, B.G.; Keijser, B.J.F.; Crielaard, W.; Lagerweij, M.D. Caries Incidence in a Healthy Young Adult Population in Relation to Diet. JDR Clin. Transl. Res. 2017, 2, 142-150. [CrossRef]

20. Ekuni, D.; Furuta, M.; Irie, K.; Azuma, T.; Tomofuji, T.; Murakami, T.; Yamashiro, T.; Ogura, T.; Morita, M. Relationship between Impacts Attributed to Malocclusion and Psychological Stress in Young Japanese Adults. Eur. J. Orthod. 2011, 33, 558-563. [CrossRef]

21. Greene, J.C.; Vermillion, J.R. The simplified oral hygiene index. J. Am. Dent. Assoc. 1964, 68, 7-13. [CrossRef] 
22. Saho, H.; Taniguchi-Tabata, A.; Ekuni, D.; Yokoi, A.; Kataoka, K.; Fukuhara, D.; Toyama, N.; Islam, M.M.; Sawada, N.; Nakashima, Y.; et al. Association between Household Exposure to Secondhand Smoke and Dental Caries among Japanese Young Adults: A Cross-Sectional Study. Int. J. Environ. Res. Public. Health 2020, 17, E8623. [CrossRef]

23. Martignon, S.; Roncalli, A.G.; Alvarez, E.; Aránguiz, V.; Feldens, C.A.; Buzalaf, M.A.R. Risk Factors for Dental Caries in Latin American and Caribbean Countries. Braz. Oral Res. 2021, 35, e053. [CrossRef] [PubMed]

24. Jung, W.-S.; Kim, H.; Park, S.-Y.; Cho, E.-J.; Ahn, S.-J. Quantitative Analysis of Changes in Salivary Mutans Streptococci after Orthodontic Treatment. Am. J. Orthod. Dentofac. Orthop. 2014, 145, 603-609. [CrossRef] [PubMed]

25. Isaksson, H.; Alm, A.; Koch, G.; Birkhed, D.; Wendt, L.K. Caries Prevalence in Swedish 20-Year-Olds in Relation to Their Previous Caries Experience. Caries Res. 2013, 47, 234-242. [CrossRef] [PubMed]

26. Karlsson, F.; Stensson, M.; Jansson, H. Caries Incidence and Risk Assessment during a Five-Year Period in Adolescents Living in South-Eastern Sweden. Int. J. Dent. Hyg. 2020, 18, 92-98. [CrossRef]

27. Lee, H.-J.; Kim, J.-B.; Jin, B.-H.; Paik, D.-I.; Bae, K.-H. Risk Factors for Dental Caries in Childhood: A Five-Year Survival Analysis Community Dent. Oral Epidemiol. 2015, 43, 163-171. [CrossRef]

28. Sonoda, C.; Ebisawa, M.; Nakashima, H.; Sakurai, Y. Dental Caries Experience, Rather than Toothbrushing, Influences the Incidence of Dental Caries in Young Japanese Adults. Community Dent. Health 2017, 34, 118-121. [CrossRef]

29. Marinho, V.C.C.; Chong, L.Y.; Worthington, H.V.; Walsh, T. Fluoride Mouthrinses for Preventing Dental Caries in Children and Adolescents. Cochrane Database Syst. Rev. 2016, 7, CD002284. [CrossRef]

30. Belotti, L.; Frazão, P. Effectiveness of Water Fluoridation in an Upper Middle-Income Country: Systematic Review and MetaAnalysis. Int. J. Paediatr. Dent. 2021. Online ahead of print. [CrossRef]

31. Moynihan, P.; Petersen, P.E. Diet, Nutrition and the Prevention of Dental Diseases. Public Health Nutr. 2004, 7, 201-226. [CrossRef]

32. Lombardo, L.; Ortan, Y.Ö.; Gorgun, Ö.; Panza, C.; Scuzzo, G.; Siciliani, G. Changes in the Oral Environment after Placement of Lingual and Labial Orthodontic Appliances. Prog. Orthod. 2013, 14, 28. [CrossRef]

33. Komiyama, K.; Kimoto, K.; Taura, K.; Sakai, O. National Survey on School-Based Fluoride Mouth-Rinsing Programme in Japan Regional Spread Conditions from Preschool to Junior High School in 2010. Int. Dent. J. 2014, 64, 127-137. [CrossRef] [PubMed]

34. Ferreira Zandoná, A.; Santiago, E.; Eckert, G.J.; Katz, B.P.; Pereira de Oliveira, S.; Capin, O.R.; Mau, M.; Zero, D.T. The Natural History of Dental Caries Lesions: A 4-Year Observational Study. J. Dent. Res. 2012, 91, 841-846. [CrossRef] [PubMed]

35. Japanese National Survey of Dental Diseases in 2016. Available online: https:/ /www.e-stat.go.jp/stat-search/files?page=1\& layout $=$ datalist\&toukei $=00450131 \& t s t a t=000001104615 \&$ cycle $=0 \&$ result_page $=1 \& t c l a s s 1 \mathrm{val}=0$ (accessed on 25 December 2021).

36. Batchelor, P.A.; Sheiham, A. Grouping of Tooth Surfaces by Susceptibility to Caries: A Study in 5-16 Year-Old Children. BMC Oral Health 2004, 4, 2. [CrossRef] [PubMed]

37. Clark, D.C.; Berkowitz, J. The Relationship between the Number of Sound, Decayed, and Filled Permanent Tooth Surfaces and the Number of Sealed Surfaces in Children and Adolescents. J. Public Health Dent. 1997, 57, 171-175. [CrossRef] [PubMed]

38. Ndagire, B.; Mwesigwa, C.L.; Ntuulo, J.M.; Mayanja-Kizza, H.; Nakanjako, D.; Rwenyonyi, C.M. Dental Caries Pattern and Treatment Needs among Ugandan Adolescent Students: A Cross-Sectional Study. Int. J. Dent. 2020, 2020, 8135865. [CrossRef]

39. Wang, X.; Bernabe, E.; Pitts, N.; Zheng, S.; Gallagher, J.E. Dental Caries Thresholds among Adolescents in England, Wales, and Northern Ireland, 2013 at 12, and 15 Years: Implications for Epidemiology and Clinical Care. BMC Oral Health 2021, $21,137$. [CrossRef] [PubMed]

40. Macek, M.D.; Beltrán-Aguilar, E.D.; Lockwood, S.A.; Malvitz, D.M. Updated Comparison of the Caries Susceptibility of Various Morphological Types of Permanent Teeth. J. Public Health Dent. 2003, 63, 174-182. [CrossRef]

41. Kunitomo, M.; Ekuni, D.; Mizutani, S.; Tomofuji, T.; Irie, K.; Azuma, T.; Yamane, M.; Kataoka, K.; Taniguchi-Tabata, A.; Mizuno, H.; et al. Association between Knowledge about Comprehensive Food Education and Increase in Dental Caries in Japanese University Students: A Prospective Cohort Study. Nutrients 2016, 8, 114. [CrossRef]

42. Yamane-Takeuchi, M.; Ekuni, D.; Mizutani, S.; Kataoka, K.; Taniguchi-Tabata, A.; Azuma, T.; Furuta, M.; Tomofuji, T.; Iwasaki, Y.; Morita, M. Associations among Oral Health-Related Quality of Life, Subjective Symptoms, Clinical Status, and Self-Rated Oral Health in Japanese University Students: A Cross-Sectional Study. BMC Oral Health 2016, 16, 127. [CrossRef]

43. Afrashtehfar, K.I.; Tamimi, F. An online tool that provides access to evidence-based literature on dental restorations: www.crownorfill.com. J. Prosthet. Dent. 2017, 118, 696-697. [CrossRef]

44. Afrashtehfar, K.I.; Emami, E.; Ahmadi, M.; Eilayyan, O.; Abi-Nader, S.; Tamimi, F. Failure rate of single-unit restorations on posterior vital teeth: A systematic review. J. Prosthet. Dent. 2017, 117, 345-353.e8. [CrossRef] [PubMed]

45. Afrashtehfar, K.I.; Ahmadi, M.; Emami, E.; Abi-Nader, S.; Tamimi, F. Failure of single-unit restorations on root filled posterior teeth: A systematic review. Int. Endod. J. 2017, 50, 951-966. [CrossRef] [PubMed]

46. Pitts, N.B.; Ekstrand, K.R. ICDAS Foundation. International Caries Detection and Assessment System (ICDAS) and its International Caries Classification and Management System (ICCMS)—Methods for staging of the caries process and enabling dentists to manage caries. Community Dent. Oral Epidemiol. 2013, 41, 41-52. [CrossRef] [PubMed]

47. Featherstone, J.D.B.; Crystal, Y.O.; Alston, P.; Chaffee, B.W.; Doméjean, S.; Rechmann, P.; Zhan, L.; Ramos-Gomez, F.A. Comparison of Four Caries Risk Assessment Methods. Front. Oral Health. 2021, 2, 656558. [CrossRef] 